\title{
Üniversite-Sanayi İşbirliği Uygulamasının Mobilya ve Dekorasyon Programı Mezunları Açısından Değerlendirilmesi
}

\author{
Ayşin AŞKIN ${ }^{*}$, Faruk ÇETİN ${ }^{1}$, Yıldız ÇABUK ${ }^{2}$ \\ ${ }^{1}$ ÇOMÜ, Biga Meslek Yüksekokulu, Mobilya ve Dekorasyon Programı, 17200, Biga/ÇANAKKALE \\ Bartın Üniversitesi, Orman Fakültesi, Orman Endüstri Mühendisliği Bölümü,74100, BARTIN
}

\section{Öz}

$\mathrm{Bu}$ çalışma Mobilya ve Dekorasyon Programından mezun olan öğrencilerin, üniversite sanayi işbirliği çerçevesinde aldıkları ön lisans eğitimlerinin iş hayatlarına olan katkısını tespit etmek amacıyla gerçekleştirilmiştir. $\mathrm{Bu}$ amaç doğrultusunda okul, meslek, mezuniyet sonrası bilgileri ve üniversite-sanayi işbirliğine yönelik görüşleri tespit edilmiştir. Araştırma evrenini Çanakkale Onsekiz Mart Üniversitesi, Biga Meslek Yüksekokulu Mobilya ve Dekorasyon programından 2008-2019 yılları arasında mezun olmuş 185 öğrenci oluşturmuştur. Veriler anket yöntemi ile elde edilmiş ve değerlendirilmiştir. Çalışma sonucunda mezunların okulda meslekleri ile ilgili aldıkları eğitimin yeterli olduğunu düşündükleri anlaşılmıştır. İşe yerleşmedeki en önemli faktörün tecrübe olduğu, iş yerinde kendilerinde yetersiz/eksik gördükleri faktörlerin ise yabancı dil ve tecrübe/deneyim olduğu belirlenmiştir. Üniversite sanayi işbirliği çerçevesinde alınan uygulamalı eğitimlerin, mesleki gelişimlerine, mobilya sektörünü daha yakından tanımalarına ve bilgilenmelerine önemli katkı sağladığı anlaşılmıştır.

Anahtar Kelimeler: Üniversite-sanayi işbirliği, işbaşı eğitim, meslek yüksekokulu, teknik eğitim.

\section{Evaluation of the Application of University-Industry Cooperation in Terms of Furniture and Decoration Program Graduates}

\begin{abstract}
This study was conducted to determine the contribution of associate degree education, received by Furniture and Decoration Program graduates within the frame of university-industry cooperation, to their working life. In line with this purpose, the school, occupation and postgraduate knowledge of the graduates and their views on university-industry cooperation were determined. The population of the study comprised of 185 students who graduated from Canakkale Onsekiz Mart University, Biga Vocational School, Furniture and Decoration Program between 2008-2019. The data were acquired and assessed via survey method. As a result of the study, it was seen that the graduate considered the education, they received concerning their occupation at school, as adequate. It was determined that the most important factor in job placement was experience and foreign language and experience to be among the elements they considered insufficient in the workplace. It was understood that the practical trainings received within the frame of university-industry cooperation, made important contributions to occupational development of the graduates and considerably enabled them to be closely acquainted with and get informed about the furniture sector.
\end{abstract}

Keywords: University-industry cooperation, on-the-job training, vocational school, technical training.

*Sorumlu Yazar (Corresponding Author):

Ayşin AŞKIN (Dr.); Çanakkale Onsekiz Mart Üniversitesi, Biga Meslek

Yüksekokulu, Mobilya ve Dekorasyon Programı, 17200, Biga, Çanakkale-Türkiye.

Tel: +90 (286) 316 2878, E-mail: aysinaskin@ comu.edu.tr,

ORCID: 0000-0001-8573-3518 


\section{Giriş}

Teknolojinin büyük bir hızla geliştiği günümüz koşulları, tüm dünyada rekabet koşullarını artırmış ve bu değişime ayak uydurulmasını zorunlu hale getirmiştir. Gelişmiş ülkeler ile az gelişmiş ülkeler arasındaki farka bakıldığında en önemli farkın yetişmiş insan gücü olduğu görülmektedir. Eğitim seviyesi arttıkça nitelikli işgücü ihtiyacı da karşılanmaktadır (Kokmaz, 2015). Tüm dünyada yaşanan bu gelişmeler nitelikli insan gücüne olan gereksinimi ortaya çıkarmıştır (Yörük vd., 2002). Nitelikli insan gücünün yetiştirilmesinin ülkelerin ekonomik açıdan kalkınmasına katkısı çok büyüktür. Nitelikli işgücüne ulaşmanın en temel yolu mesleki eğitimden geçmektedir. Eğitim, ülkelerde sürdürülebilir büyümeyi sağlayan beşeri sermayenin, yani insanın niteliğinin iyileştirilmesindeki önemli faktördür (Kokmaz, 2015). Mesleki eğitim ise kişilere bir meslek dalı ile ilgili bilgi ve beceri kazandırılması, meslekle ilgili alışkanlıkların ve kişinin yeteneklerinin geliştirilmesinin sağlanmasıdır. Meslek Yüksekokulları ülkemizde bu eğitimlerin sağlandığı önemli kurumlardır. Bu okullar sektörün ihtiyaç duyduğu nitelikli elemanların yetiştirilmesini sağlayarak, istihdama büyük katkı sunmaktadırlar. Bu okullardan mezun olan öğrenciler tekniker unvanı almaktadır. Teknikerler özellikle üretim süreçlerinde mühendislerin önemli yardımcıları konumunda yer almaktadırlar. Küçük işletmelerde teknikerlerin mühendis rolü üstlenebilecek bilgiye ve yeteneğe sahip olacağı düşünülmektedir (Sönmez, 2011). Bu nedenle de bu okul mezunlarının uygulama becerilerinin mühendislerden fazla, teorik bilgilerinin ise teknisyenlerden fazla olması beklenmektedir (Adigüzel, 2009).

Meslek Yüksekokullarının çeşitli sorunları bulunmaktadır. En önemli sorunlarından bir tanesi alt yapı eksikliğidir (uygulama, laboratuar, atölye) (Alkan ve ark., 2014; Ceylan ve Erbir, 2015; Kalkınma Bakanlığı, 2014; Küçükgöksel ve Akpınar 2016; Tuncer ve Tanas, 2019, Yıldırım ve ark., 2017). Günümüzde Meslek Yüksekokulu bünyesinde yer alan bir çok Mobilya ve Dekorasyon Programı çeşitli nedenlerden dolayı (öğrenci tercih etmemesi vb.) kapanmıştır. Bazı bölümler ise altyapısını geliştirmiş, bir kısmı da 3+1 eğitim sistemi modeline geçmiştir. 3+1 eğitim sistemi ile Meslek Yüksekokullarının bir çok önemli probleminin (alt yap1 eksikliği, sektör beklentilerinin karşılanamaması vb.) ortadan kaldırılacağı ve bu sistem ile Meslek Yüksekokullarının tercih edilme oranlarının da artmasına imkân sağlayacağı beklenmektedir (Yıldırgan, 2016).

Okulda mesleki bilgilerini ve uygulamalarını tam edinemeyen öğrencilerin çalışma hayatında iş ile ilgili bilgileri öğrenmeleri ayrıca bir zaman gerektirmektedir. Birçok işyeri üniversiteden yeni mezun olmuş çalışanların iş ile ilgili yeterli seviyede olmadığını düşünmektedir. Bu nedenle de işyerinde işe başladıklarında işyerine özgü kurallar ve işleyişi öğretmenin yanında, okulda öğrenilmesi gereken temel ve uygulama bilgileri de öğretilmektedir. Bu durum ise hem ekonomik açıdan hem de çalışanlar açısından önemli kayıplara neden olmaktadır (Sönmez, 2011). Bunun giderilmesi için okulda teorik bilgilerin yanı sıra uygulamalı eğitimlerin de verilmesi gerekmektedir (Adıgüzel, 2009). Uygulamalı eğitim mesleki eğitimin en önemli kısmını oluşturur. Sektörün ihtiyaç duyduğu özellikte elemanların yetiştirilmesi iyi bir eğitim ortamının sağlanmasını gerektirmektedir. Bu koşullar ise özelikle uygulamaların yapıldığı atölye ve laboratuvar sınıflarının sanayide kullanılan teknolojiye uygun biçimde düzenlenmiş olmasını gerektirir. Ancak bu donanımların maliyetleri çok yüksektir. Birçok okulda da uygulama ortamları yetersizdir (Koşan, 2003).

Okullarda elde edilen teorik bilgileri uygulamaya dönüştürülebilmenin en önemli yollarından bir tanesi de eğitim amaçlı kurulan üniversite-sanayi işbirliği ortaklığının sağlanmasıdır (Adıgüzel, 2009). İşbirliği çalışmaları kısaca üniversiteler ve sanayinin imkânlarının birleştirilmesi ile yapılan bilimsel, teknolojik ve ekonomik gelişme amaçlı çalışmalardır (İmamoğlu, 2004). İçinde bulunduğumuz şartlar mezun öğrencilerden beklentileri de değiştirmiştir. Bu nedenle özellikle; bu değişimlere uyum sağlayabilen, teknolojiyi kullanabilen, kendini geliştirebilen, problem çözme yeteneğine sahip, sorumluluk alabilen, çok boyutlu düşünen, yenilikçi özellikteki kişilere ihtiyaç duyulmaktadır (Ulus vd., 2015). Üniversite sanayi işbirliği çalışmalarının hem öğrenci hem sektör hem de toplum açısından önemli faydaları bulunmaktadır. Öğrencilerin teorik bilgiler ile uygulama becerilerinin bütünleşmesi sağlanarak gerçek iş ortamında da uygulanması sağlanır, kişilerde ekip ruhu ve takım anlayışı gelişir. Sektörler nitelikli eleman konusunda alt yapıları oluşturur, işe almayı düşündüğü kişileri önceden değerlendirme firsatı bulur ve böylece çalışanların işe uyum süreçleri kısalır. Toplum açısından da toplumun üretim isteğinin ve gücünün artırılmasına ve ekonomik açıdan deneyimli kişilerin yetiştirilmesine imkân sağlanmış olur (Sevim ve Karamete, 2003).

\section{Materyal ve Metot}

\subsection{Materyal}


Araştırma evrenini Çanakkale Onsekiz Mart Üniversitesi Biga Meslek Yüksekokulu Mobilya ve Dekorasyon programından 2008-2019 yılları arasında mezun olmuş toplam 185 öğrenci oluşturmaktadır. Çalışmada \% 95 güven aralığında hesaplanan örneklem büyüklüğü $125^{\prime}$ tir. Bu çalışmada 138 veri elde edilmiştir. Örneklem büyüklüğü aşağıda belirtilen eşitlik doğrultusunda belirlenmiştir:

$\mathrm{n}=\mathrm{Nt}^{2} \mathrm{pq} / \mathrm{d}^{2}(\mathrm{~N}-1)+\mathrm{t}^{2} \mathrm{pq}(\mathrm{N}$ :Evrendeki birey sayıs1; $\mathrm{n}$ :örnekleme alınacak birey sayısı; $\mathrm{p}$ :incelenen olayın görülme sıklığı (olasılığı); q: incelenen olayın görülmeme sıklığı (olasılığı); t: belirli serbestlik derecesinde ve saptanan yanılma düzeyinde $t$ tablosundan bulunan teorik değer; d:Olayın görülme sıklığına göre yapılmak istenen \pm sapma).

\subsection{Metot}

Çanakkale Onsekiz Mart Üniversitesi, Biga Meslek Yüksekokulu Mobilya ve Dekorasyon Programı 2006 yılında eğitim öğretim faaliyetine başlamıştır. Aynı yıl bölgede yer alan ve ülkemiz mobilya sektörünün en önemli kuruluşlarından olan Doğtaş Kelebek Mobilya A.Ş. ile üniversite-sanayi işbirliği çalışması çerçevesinde işbirliği protokolü gerçekleştirilmiştir. Protokol çerçevesinde öğrenciler teorik derslerini okulda, uygulama derslerini ise birinci sınıf güz ve bahar yarıyılı olmak üzere iki dönem fabrikada, ikinci sınıfta Meslek Yüksekokulu bünyesinde bulunan uygulama atölyesinde gerçekleştirmişlerdir. Bu çalışma Biga Meslek Yüksekokulu Mobilya ve Dekorasyon Programından mezun olan öğrencilerin, okul ve mesleğe yönelik görüşleri ile mezuniyet sonrasına yönelik bilgileri ve üniversite sanayi işbirliği çerçevesinde aldıkları uygulamalı eğitimin iş hayatlarına olan katkısını belirlemek amacıyla gerçekleştirilmiştir.

Araştırma verilerinin elde edilmesinde anket yöntemi uygulanmıştır. Hazırlanan anket çalışması üç kısımdan oluşmuştur. Birinci bölüm öğrencilerin genel bilgilerini belirlemeye yönelik sorulardan (sosyo-demografik) (13 soru), ikinci bölüm çalışılan iş ve okudukları bölümlerine yönelik sorulardan ( 9 soru), üçüncü bölüm ise üniversite sanayi işbirliği çerçevesinde aldıkları eğitime yönelik sorulardan (17 soru) oluşmaktadır. Veriler SPSS 20 paket programı ile değerlendirilerek analiz edilmiştir. Tanımlayıcı verilerin sunumunda frekans ve yüzde değerleri kullanılmıştır.

Seçenekli soruların(katılıorum/katılmıyorum/kararsızım/katılmıyorum/hiçkatılmıyorum) değerlendirilmesinde; tamamen katılıyorum, katılıyorum ifadelerinin yer aldığı bölümün değerleri toplamı, aynı seçenekte sunulan diğer olumsuz yanıtlar olan katılmıyorum, hiç katılmıyorum ifadelerinin yer aldığı kategorilerin toplamından büyük ise olumlu tutum gösterdiği yönünde değerlendirilmiştir. Anket sorularının hazırlanmasında; Adıgüzel (2009), Faik (2010), Akşit (2016) ve Arpat (2018)'ın çalışmalarından yararlanılmıştır.

\section{Bulgular ve Tartışma}

\subsection{Demografik Özelliklere İlişkin Bulgular}

Öğrencilerin demografik verilerine ait bulgular Şekil 1'de gösterilmiştir. Mobilya ve Dekorasyon Programından mezun olan öğrencilerin \%93'ü erkek, \%7'si bayan'dır. Yaş dağılımlarına göre öğrencilerin \%48'i 25-29, \%32'si 20-24,, \%20'si 30-34 yaş aralığındadır. Medeni durumlarına göre öğrencilerin \%67'si bekâr, \%33'ü ise evlidir. Mezun oldukları lise türüne göre \%83'ü meslek lisesi, \%13’ü düz lise, \%4'ü ise diğer lise türlerinden mezun olmuşlardır (Şekil 1).
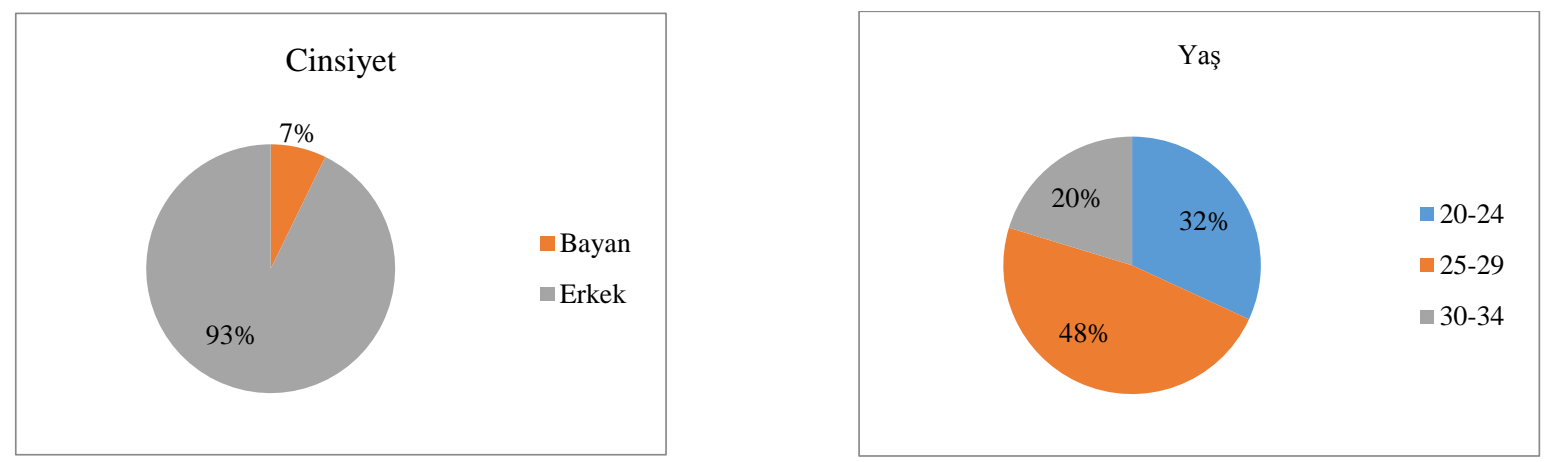

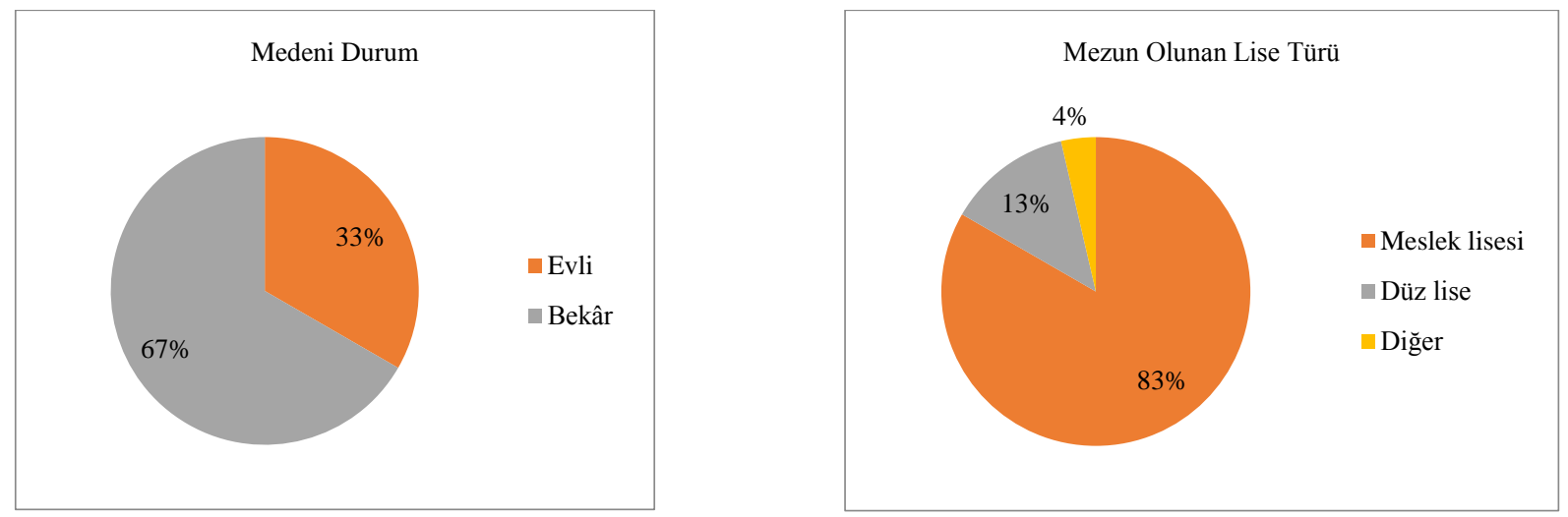

Şekil 1. Demografik bilgiler

\subsection{Mezun Olunan Bölüm İlişkin Bulgular}

Öğrencilerin Mobilya ve Dekorasyon Programı tercihinde bölüm hakkında bilgi sahibi olma ve mezuniyet sonrasına yönelik eğitim hayatına devam etme bilgilerinin incelenmesine göre; üniversite sınavı yerleştirmelerinde \% 75'inin bölüm tercihinde bilgi sahibi olduğu, \%9'unun bilgisi olmadığı, \%16'sının ise kısmen bilgisi olduğu anlaşılmıştır. Bölümün istihdam olanakları ile ilgili bilgi sahibi olma durumlarına göre ise \%65'inin bilgi sahibi olduğu, \%17'sinin olmadı̆̆ tespit edilmiştir.

Meslek Yüksekokulu'ndan mezun olduktan sonra geçen süreye göre değerlendirilmesinde; öğrencilerin \%14'ünün 0-1 y1l, \%20'sinin 1-3 y1l, \% 28'inin 4-6 y1l, \%19'unun 7-9 y11, \%9'unun 10 yıl ve daha fazla zaman geçmiş olduğu belirlenmiştir. Üniversiteden mezun olduktan sonra eğitim hayatına devam etme durumlarına göre öğrencilerin \%37'sinin açık öğretim fakültesi, dikey geçiş sınavı ve yüksek öğretime geçiş sınavları ile yüksek öğretime devam ettiği, \%63'ünün devam etmediği tespit edilmiştir. Devam edilen bölüme yönelik olarak elde edilen bulgularda ise öğrencilerin \%26,8'inin açık öğretim fakültelerinin işletme bölümünü tercih ettiği anlaşılmıştır. Bunu takiben \%1,4 oranları ile dikey geçiş sınavı ile iç mimarlık ve çevre tasarımı ile endüstri ürünleri tasarımı bölümlerinin tercih edildiği anlaşılmıştır (Şekil 2).
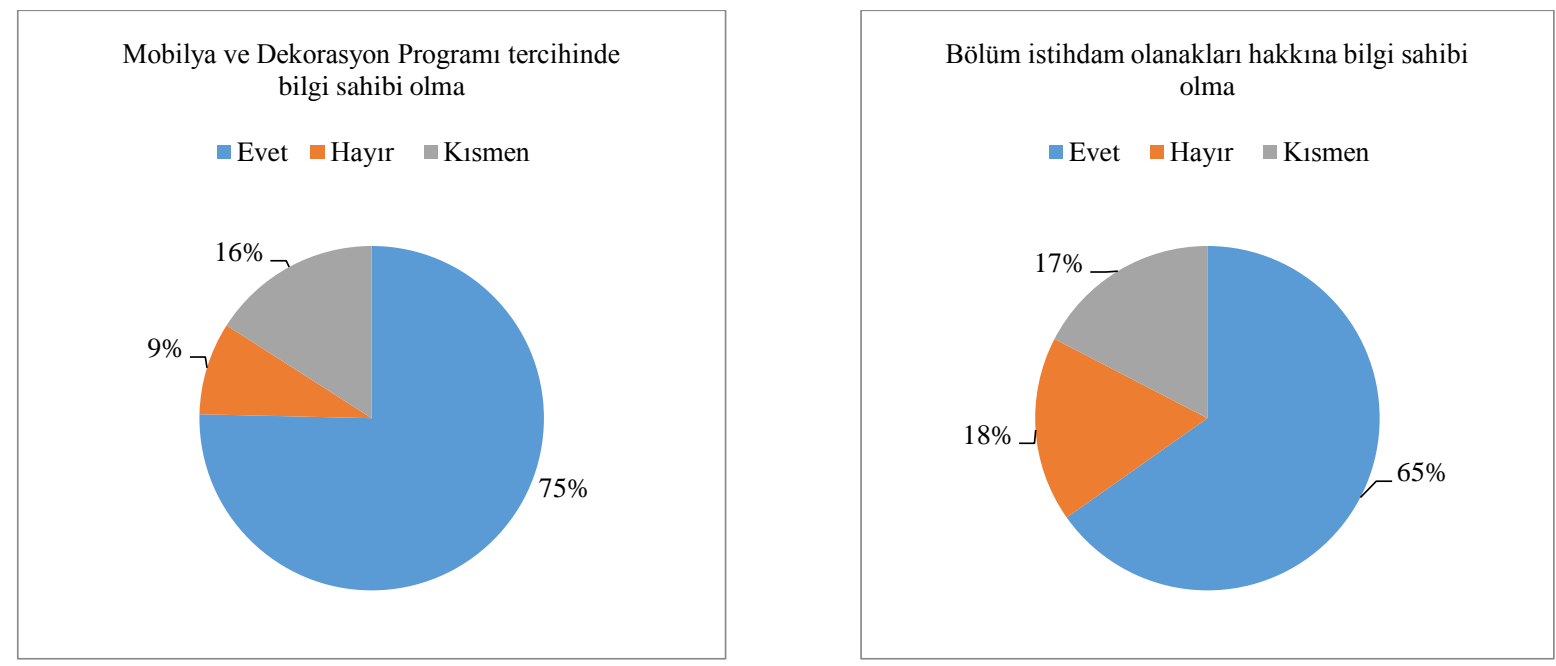

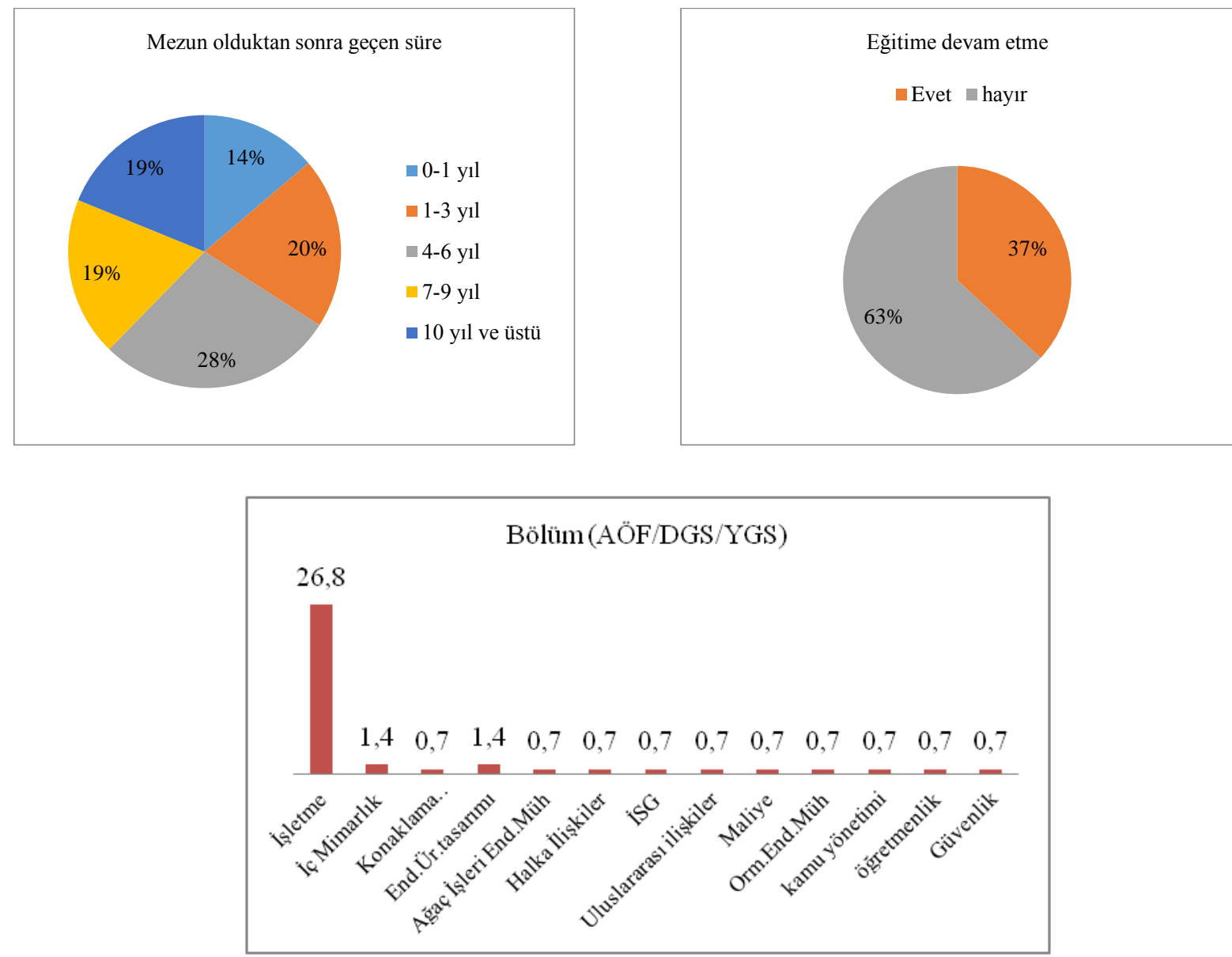

Şekil 2. Bölüm bilgileri

\subsection{Mezuniyet Sonrasına Yönelik Bulgular}

Mezuniyet sonrasında çalıştıkları sektörün belirlenmesine yönelik olarak elde edilen veriler Şekil 3'te gösterilmektedir. Buna göre mezun öğrencilerin \%59'u özel sektörde, \%11'i kamu sektöründe, \% 15 'si kendi iş yerinde iş hayatlarına devam etmektedir. Çalışmayanların oranı $\% 15$ 'tir. Çalışanların \%28'sinin mezun oldukları bölüm ile ilgili bir işte çalıştı̆̆ı, \%57'sinin farklı meslek dallarında çalıştıkları anlaşılmıştır (askeri personel, tekstil, turizm, güvenlik personeli, çiftçilik, otomotiv sektörü, hizmet sektörü vd.) (Şekil 3).

Anketi yanıtlayanların $\% 47^{\prime}$ sinin tecrübe, $\% 23^{\prime}$ ünün referans, $\% 13$ ' ünün diğer, $\% 12$ ' sinin diploma, $\% 5$ 'inin ise staj yapılan yerin işe yerleşmede önemli bir faktör olduğunu düşündükleri anlaşılmıştır. Çalıştıkları işyerinde kendilerinde yetersiz olarak gördükleri hususlara yönelik \%38'i yabancı dil, \%36'sı tecrübe-deneyim, \%11'i uygulama-pratik, 8'i yetenek ve \%7'si ise aldıkları eğitim olarak düşünmekte oldukları anlaşılmıştır (Şekil 3).
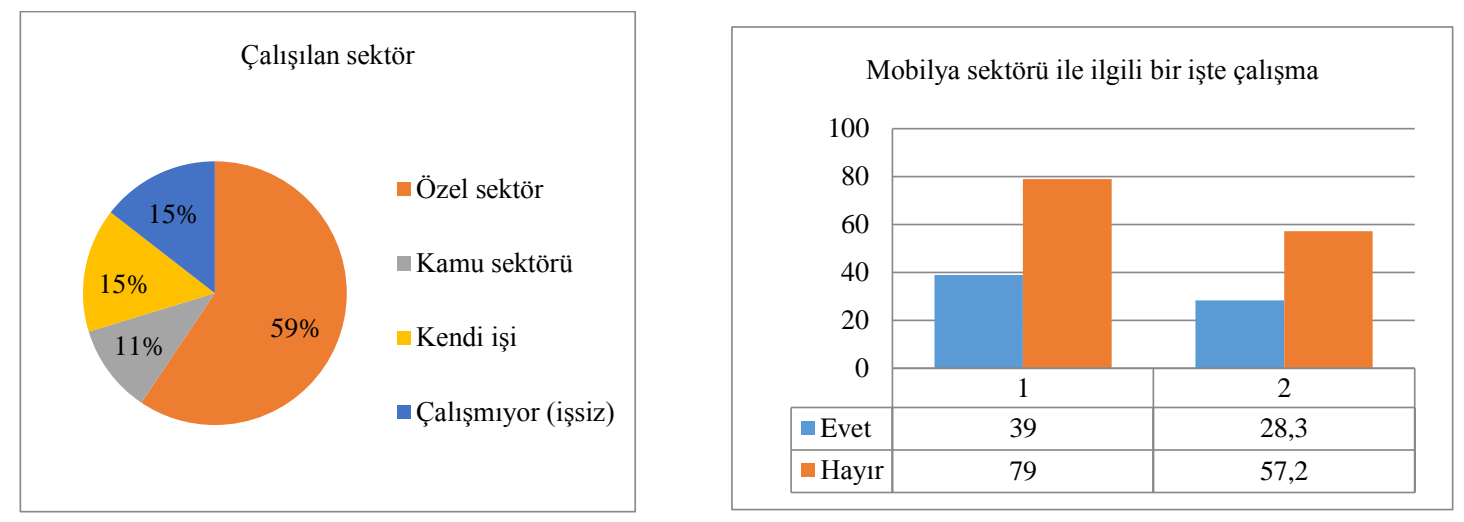

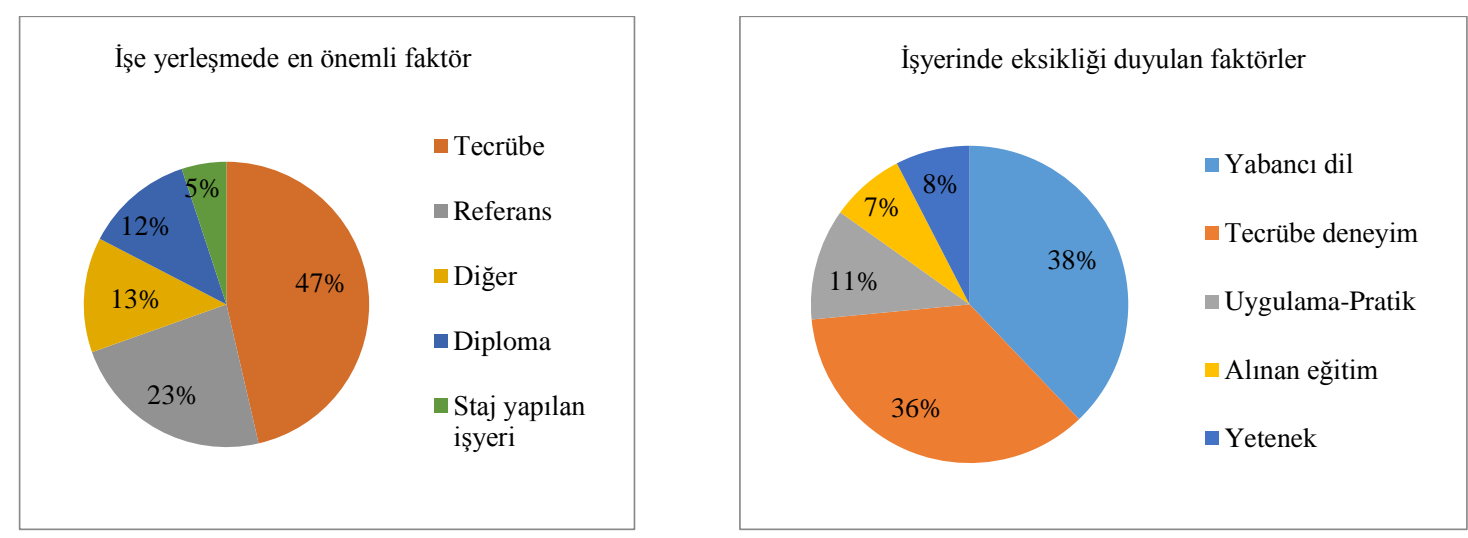

Şekil 3. Mezuniyet sonrası ile ilgili görüşler.

\subsection{Okul ve Mesleğe Yönelik Bulgular}

Mezunların okul ve mesleklerine ilişkin görüşlerine yönelik olarak elde edilen bulgular Tablo 1'de gösterilmiştir. Okulları ile bölgedeki mobilya sektörü kuruluşları arasında iletişimin yeterli olduğunu düşünme durumuna; \%40,6's1 kat1liyorum, \%32'6's1 ise tamamen katılıyorum,\%13,8'si ise kararsız olduklar1 yönünde yanıt vermişlerdir. Okulun, mezunların istihdamına destek olduğunu düşünme oranlarına göre \%16,7'si tamamen katılıyorum, \%39,1'i katılıyorum, \%21,7'si kararsızım, \%17,4'ü katılmıyorum yanıtını vermişlerdir. Mezun olduktan sonra iş bulma konusunda zorluk çekme durumlarına yönelik olarak \%26,1'i katılmıyorum, \%20,3'ü hiç katılmıyorum,\%17,4 kararsızım yönünde düşünürken, \%19,6'sı tamamen katılıyorum, \%16,7'si katılıyorum düşüncesindedir.

Mobilya ve Dekorasyon programı mezunu olmaktan memnunum görüşüne \%39,9'unun tamamen katılmakta, \%38,4'ü katılmakta; mobilya sektörü ülkemizde önemli bir sektördür görüşüne \%70'i tamamen katılmakta \%29'u katılmakta; okulda mesleğim ile ilgili yeterli düzeyde eğitim aldığımı düşünüyorum görüşüne \%39,9'u tamamen katılmakta, \%36,2'si katılmakta; bu alanda eğitim almamış arkadaşlarımdan daha fazla bilgi ve donanıma sahibim görüşüne \%39,1'i tamamen katılmakta, \%34,8'i katılmakta; okulda aldığım eğitimin bu meslekte sorunları çözebilecek bilgi, donanım ve beceriye sahip olmamı sağladığını düşünüyorum görüşüne \%32'si tamamen katılmakta, \%45'i katılmakta; okulda alınan eğitimin bu meslekte sorunları çözebilecek bilgi, donanım ve beceriye sahip olmalarını sağladığını düşünme durumuna öğrencilerin \%31,9'u tamamen katılmakta, \%45,7'si ise katılmaktadır; mobilya sektöründe çalışanların bu mesleğin eğitimini alması gerektiğini düşünüyorum görüşüne \%61'i tamamen katılmakta, \%26,8'i katılmaktadır (Tablo 1).

Tablo1. Okul ve mesleğe yönelik bilgiler

\begin{tabular}{|c|c|c|c|c|c|c|c|c|c|c|}
\hline \multirow{2}{*}{ Okul ve mesleğe yönelik bilgiler* } & \multicolumn{2}{|c|}{$\begin{array}{l}\text { Tamamen } \\
\text { Katıliyorum }\end{array}$} & \multicolumn{2}{|c|}{ Katıliyorum } & \multicolumn{2}{|c|}{ Kararsızım } & \multicolumn{2}{|c|}{ Katılmıyorum } & \multicolumn{2}{|c|}{$\begin{array}{l}\text { Hiç } \\
\text { Katılmıyorum }\end{array}$} \\
\hline & $\mathrm{n}$ & $\%$ & $\mathrm{n}$ & $\%$ & $\mathrm{n}$ & $\%$ & $\mathrm{n}$ & $\%$ & $\mathrm{n}$ & $\%$ \\
\hline $\begin{array}{lcc}\text { Okulum } & \text { ile bölgedeki } & \text { mobilya } \\
\text { sektörü } & \text { kuruluşları } & \text { arasında } \\
\text { iletişimin } & \text { yeterli } & \text { olduğunu } \\
\text { düşünüyorum } & & \end{array}$ & 45 & $\begin{array}{c}32 \\
6\end{array}$ & 56 & $\begin{array}{c}40, \\
6\end{array}$ & 19 & $\begin{array}{c}13 \\
8\end{array}$ & 11 & 8 & 7 & 5,1 \\
\hline $\begin{array}{l}\text { Okulun, mezunların istihdamına } \\
\text { destek olduğuna inanıyorum }\end{array}$ & 23 & $\begin{array}{c}16 \\
7\end{array}$ & 54 & $\begin{array}{c}39, \\
1\end{array}$ & 30 & $\begin{array}{c}21 \\
7\end{array}$ & 24 & $\begin{array}{c}17 \\
4\end{array}$ & 7 & 5,1 \\
\hline $\begin{array}{l}\text { Mezun olduktan sonra iş bulmada } \\
\text { zorlandım. }\end{array}$ & 27 & $\begin{array}{c}19, \\
6\end{array}$ & 23 & $\begin{array}{c}16 \\
7\end{array}$ & 24 & $\begin{array}{c}17 \\
4\end{array}$ & 36 & $\begin{array}{c}26, \\
1\end{array}$ & 28 & $\begin{array}{c}20, \\
3\end{array}$ \\
\hline $\begin{array}{l}\text { Mobilya ve dekorasyon programı } \\
\text { mezunu olmaktan memnunum. }\end{array}$ & 55 & $\begin{array}{c}39 \\
9\end{array}$ & 53 & $\begin{array}{c}38 \\
4\end{array}$ & 16 & $\begin{array}{c}11 \\
6\end{array}$ & 9 & 6,5 & 5 & 3,6 \\
\hline $\begin{array}{l}\text { Mobilya sektörü ülkemizde önemli } \\
\text { bir sektördür }\end{array}$ & 84 & 70 & 40 & 29 & 6 & 4,3 & 6 & 4,3 & 2 & 1,4 \\
\hline
\end{tabular}


Tablo1. Devam ediyor.

\begin{tabular}{|c|c|c|c|c|c|c|c|c|c|c|}
\hline $\begin{array}{l}\text { Okulda mesleğim ile ilgili yeterli } \\
\text { düzeyde eğitim aldım. }\end{array}$ & 55 & $\begin{array}{c}39 \\
9\end{array}$ & 50 & $\begin{array}{c}36 \\
2\end{array}$ & 18 & 13 & 8 & 5,8 & 7 & 5,1 \\
\hline $\begin{array}{l}\mathrm{Bu} \text { alanda eğitim almamış iş } \\
\text { arkadaşlarımdan daha bilgili ve } \\
\text { donanımlıyım. }\end{array}$ & 54 & $\begin{array}{c}39 \\
1\end{array}$ & 48 & $\begin{array}{c}34 \\
8\end{array}$ & 23 & $\begin{array}{c}16 \\
7\end{array}$ & 10 & 7,2 & 3 & 2,2 \\
\hline $\begin{array}{l}\text { Okulda aldığım eğitimin bu } \\
\text { meslekte sorunları çözebilecek } \\
\text { bilgi, donanım ve beceriye sahip } \\
\text { olmamı sağladığını düşünüyorum. }\end{array}$ & 44 & $\begin{array}{c}31, \\
9\end{array}$ & 63 & $\begin{array}{c}45 \\
7\end{array}$ & 22 & $\begin{array}{c}15, \\
9\end{array}$ & 9 & 6,5 & - & - \\
\hline $\begin{array}{l}\text { Mobilya sektöründe çalışanların bu } \\
\text { mesleğin eğitimini alması } \\
\text { gerektiğini düşünüyorum }\end{array}$ & 84 & 61 & 37 & $\begin{array}{c}26, \\
8\end{array}$ & 13 & 9,4 & 2 & 1,4 & 2 & 1,4 \\
\hline
\end{tabular}

\section{5 Üniversite-Sanayi İşbirliğine Yönelik Bulgular}

Üniversite-sanayi işbirliğine yönelik sorulardan elde edilen bulgulara göre; üniversite-sanayi işbirliğinin mesleki bilgi birikimine katkı sağladığını düşünme fikrine mezunların \%48,6'sının katıldığı, \%35,5'inin ise tamamen katılıyorum görüşünde olduğu görülmektedir. İşyerinde yapılan iş ile okulda alınan eğitimin birbirine uygun olduğunu ve birbirini tamamladığı düşüncesine \%41,3'ü katılmakta, \%31,9'u tamamen katılmaktadır. İşyerindeki birim sorumlularının alınan eğitime katkı sağladığı görüşüne; \%51,4'ü katılmakta, \%23,2'si tamamen katılmaktadır (Tablo 2).

Üniversite-sanayi işbirliği iş bulmada büyük katkı sağlamıştır görüşüne \%42,8'i katıllyorken, \%17,4'ü tamamen katılmakta, \%26,8'i ise kararsız olduğunu belirtmektedir. Üniversite-sanayi işbirliği eğitim uygulamasını gerçekleştirmeyen aynı bölüm diğer Meslek Yüksekokul mezunlarından daha avantajlı olduğumu düşünüyorum görüşüne \%45,7'si katılmakta, \%29,7'si tamamen katılmakta olup, \%19,6'sı ise kararsızdır (Tablo 2).

İşyerinde çalışanlarla iyi bir iletişim içerisinde olma görüşüne \%47,8'i tamamen katılmakta, \%44,2'si katılmaktadır. Üniversite-sanayi işbirliği ile okulda aldığım teorik bilgileri işyerinde kullanabildim görüşüne \%49,3'ü katılıyorken, \%32,6'sı tamamen katılmaktadır. Üniversite-sanayi işbirliği ile eğitim yapılan işyerinde, mezuniyet sonrası çalışmayı isterim düşüncesine \%34,8'inin katıldığı, \%21,7'sinin tamamen katıldığı,\%28,3'ünün ise kararsız olduğu anlaşılmıştır. Bu uygulama iş dünyasının işleyişini kavramama katkı sağladı fikrine \%49,3'ü katılmakta,\%29'u ise tamamen katılmaktadır. Mobilya sektörü çalışma koşulları hakkında bilgi sahibi oldum fikrine \%51,4'ü katılmakta, \%37'si tamamen katılmaktadır. Sektörde kullanılan makine ve araç gereçlerin kullanımı hakkında bilgi sahibi olduğunu düşünme fikrine $\% 48,6$ 'sı katılmakta, $\% 42$ 'si ise tamamen katılmaktadır (Tablo 2).

Üniversite sanayi işbirliği uygulamasının mobilya sektörü ile ilgili yeni yöntem ve tekniklerin öğrenmeme katkı sağladı görüşüne \%31,2' si tamamen katılıyorken, \%49,3'ü katılmaktadır. İş yaşamındaki ast-üst ilişkisini anladım görüşüne \%42,8'i tamamen katılmakta, \%47,1'i katılmaktadır. Bu uygulama ile mesleğe ilişkin somut bilgiler edindim görüşüne \%39,9'u tamamen katılmakta, \%.47,1'i katılmakta; teknikerlerin önemini kavradım görüşüne \%44,9'u tamamen katılmakta, \%43,5'i katılmaktadır. Mesleğe yönelik ilgimi ve özgüvenimi artırdı görüşüne \%39,1'i tamamen katılmakta, \%44,2'si katılmakta; kariyer planıma büyük katkı sağladı görüşüne \% 28,3'ü tamamen katılmakta, \%.42'si katılmaktadır (Tablo 2). 
Tablo 2. Üniversite sanayi işbirliğine yönelik bilgiler.

\begin{tabular}{|c|c|c|c|c|c|c|c|c|c|c|}
\hline \multirow[t]{2}{*}{ Üniversite-Sanayi İşbirliğï* } & \multicolumn{2}{|c|}{$\begin{array}{c}\text { Tamamen } \\
\text { Katıliyorum }\end{array}$} & \multicolumn{2}{|c|}{ Katıliyorum } & \multicolumn{2}{|c|}{ Kararsızım } & \multicolumn{2}{|c|}{ Katılmiyorum } & \multicolumn{2}{|c|}{$\begin{array}{c}\text { Hiç } \\
\text { Katılmıyorum }\end{array}$} \\
\hline & $\mathrm{n}$ & $\%$ & $\mathrm{n}$ & $\%$ & $\mathrm{n}$ & $\%$ & $\mathrm{n}$ & $\%$ & $\mathrm{n}$ & $\%$ \\
\hline $\begin{array}{l}\text { Üniversite-sanayi işbirliğinin } \\
\text { mesleki bilgi birikimime katkı } \\
\text { sağladığını düşünüyorum. }\end{array}$ & 49 & 35,5 & 67 & 48,6 & 16 & 11,6 & 6 & 4,3 & - & - \\
\hline $\begin{array}{l}\text { İşyerinde yaptığımız iş ile okulda } \\
\text { aldığımız eğitim uygun olup } \\
\text { birbirini } \\
\text { düşünüyorum }\end{array}$ & 44 & 31,9 & 57 & 41,3 & 25 & 18,1 & 8 & 5,8 & 4 & 2,9 \\
\hline $\begin{array}{l}\text { İşyerindeki birim sorumluları, } \\
\text { işbaşı eğitimime yeterince katkı } \\
\text { sağlamıştır. }\end{array}$ & 32 & 23,2 & 71 & 51,4 & 24 & 17,4 & 9 & 6,6 & 2 & 1,4 \\
\hline $\begin{array}{l}\text { Üniversite-sanayi işbirliği iş } \\
\text { bulmama katkı sağladı. }\end{array}$ & 24 & 17,4 & 59 & 42,8 & 37 & 26,8 & 14 & 10,1 & 4 & 2,9 \\
\hline $\begin{array}{l}\text { Bu uygulamayı almayanı diğer } \\
\text { mezunlardan daha avantajlı } \\
\text { olduğumu düşünüyorum. }\end{array}$ & 41 & 29,7 & 63 & 45,7 & 27 & 19,6 & 6 & 4,3 & 1 & 0,7 \\
\hline $\begin{array}{l}\text { İşyerinde çalışanlarla sağlıklı bir } \\
\text { iletişim içerisinde oldum. }\end{array}$ & 66 & 47,8 & 61 & 44,2 & 8 & 5,8 & 3 & 2,2 & - & - \\
\hline $\begin{array}{l}\text { Üniversite-sanayi işbirliği ile o } \\
\text { kulda aldığım teorik bilgileri } \\
\text { işyerinde kullanabildim. }\end{array}$ & 45 & 32,6 & 68 & 49,3 & 16 & 11,6 & 7 & 5,1 & 2 & 1,4 \\
\hline $\begin{array}{l}\text { Üniversite-Sanayi İşbirliği ile } \\
\text { İşbaşı eğitimi yaptığım işyerinde, } \\
\text { eğitimim sonrası çalışmak istedim. }\end{array}$ & 30 & 21,7 & 48 & 34,8 & 39 & 28,3 & 12 & 8,7 & 9 & 6,5 \\
\hline $\begin{array}{l}\mathrm{Bu} \text { uygulama iş dünyasının } \\
\text { işleyişini kavramama katkı sağladı. }\end{array}$ & 40 & 29 & 68 & 49,3 & 20 & 14,5 & 8 & 5,8 & 2 & 1,4 \\
\hline $\begin{array}{l}\text { Çalışma koşulları hakkında bilgi } \\
\text { sahibi oldum. }\end{array}$ & 51 & 37 & 71 & 51,4 & 9 & 6,5 & 7 & 5,1 & - & - \\
\hline $\begin{array}{l}\text { Sektörde kullanılan makine ve araç } \\
\text { gereçlerin kullanımı hakkında bilgi } \\
\text { sahibi oldum. }\end{array}$ & 58 & 42 & 67 & 48,6 & 12 & 8,7 & 1 & 0,7 & - & - \\
\hline $\begin{array}{l}\text { Sektör ile ilgili yeni yöntem ve } \\
\text { teknikleri öğrenmeme katkı } \\
\text { sağladı. }\end{array}$ & 43 & 31,2 & 68 & 49,3 & 22 & 15,9 & 3 & 2,2 & 2 & 1,4 \\
\hline $\begin{array}{l}\text { Bu uygulama ile iş yaşamındaki ast } \\
\text { üst konusunu anladım. }\end{array}$ & 59 & 42,8 & 65 & 47,1 & 13 & 9,4 & - & - & 1 & 0,7 \\
\hline $\begin{array}{l}\text { Bu uygulama ile mesleğe ilişkin } \\
\text { somut bilgiler edindim }\end{array}$ & 55 & 39,9 & 65 & 47,1 & 11 & 8 & 5 & 3,6 & 2 & 1,4 \\
\hline $\begin{array}{l}\mathrm{Bu} \text { uygulama ile teknikerlerin } \\
\text { işletmedeki önemini kavradım. }\end{array}$ & 62 & 44,9 & 60 & 43,5 & 11 & 8,0 & - & - & 5 & 3,6 \\
\hline $\begin{array}{l}\text { Mesleğe yönelik ilgimin ve } \\
\text { özgüvenimin artmasını sağladı. }\end{array}$ & 54 & 39,1 & 61 & 44,2 & 16 & 11,6 & 7 & 5,1 & - & - \\
\hline $\begin{array}{l}\text { Kariyer planlarıma büyük katkı } \\
\text { sağladı. }\end{array}$ & 39 & 28,3 & 58 & 42 & 30 & 21,7 & 8 & 5,8 & 3 & 2,2 \\
\hline
\end{tabular}

*satır yüzdesi alınmıştır.

\section{Tartışma ve Sonuç}

Cinsiyet dağılımına göre Mobilya ve Dekorasyon programı mezunlarının \%93'ü erkek, \%7'si ise bayandır. Mobilya ve Dekorasyon programı cinsiyet dağılımına göre erkek öğrencilerin ağırlıkta olduğu bir programdır. Benzer biçimde aynı bölümdeki diğer okullarda da ağırlıklı olarak erkek öğrencilerin tercih ettiği bir program olduğu görülmektedir (URL-1, 2020). Mezun olunan lise türüne göre ağırlıklı olarak (\%83) meslek lisesi 
mezunlarından oluşmaktadır. 2002-2003 öğretim yılından itibaren yürürlüğe konulan kanun kapsamında mesleki ve teknik ortaöğretim kurumlarından mezun olan öğrencilerin, istedikleri takdirde bitirdikleri programın devamı niteliğinde veya buna en yakın programların uygulandığı öncelikle kendi Mesleki ve Teknik Eğitim Bölgesi (METEB) içinde yer alan veya bölgesi dışındaki Meslek Yüksekokullarına sınavsız olarak yerleştirilebileceği hükmü getirilmiş ve uygulamaya konulmuştur (URL-2, 2020). 2017 yılı ve sonrasında tüm lise mezunları Yükseköğretim kurumlarına YGS sınavı ile yerleştirilmiştir. Anket kapsamında yer alan öğrencilerin büyük çoğunluğunu, üniversiteye sınavsız geçiş sisteminden yararlanarak devam etmiş olan öğrenciler oluşturmaktadır.

Öğrencilerin ağırlıklı olarak meslek lisesi mezunu oldukları için Mobilya ve Dekorasyon programı tercihinde (\%75) ve bölümün istihdam olanakları hakkında bilgi sahibi oldukları (\%65) ve bilinçli bir tercih yaptıkları söylenebilir. Literatürde yapılan çalışmalarda Meslek Yüksekokulu öğrencilerinin çoğunlukla dikey geçiş sınav1 ile bir bölüme yerleşmeyi hedefledikleri görülmektedir (Dündar ve Bıçakçı, 2017; Kaysi 2019). Mezun olduktan sonra eğitim hayatına devam edenlerin oranı \%37'dir. \%26,8'i Açık Öğretim Fakültelerinin işletme bölümünü tercih etmiştir. Dikey geçiş sınavı ile yerleşenlerin oranı \%1,4'tür. Dikey geçiş sınavı ile yerleşenlerin oranlarının oldukça düşük olduğu anlaşılmıştır.

Mezunların \%85'inin bir işte çalıştığı, çalışanların \%28'sinin mezun oldukları bölüm ile ilgili bir işte çalıştığ tespit edilmiştir. Literatürde ülkemiz mobilya sanayisinin en önemli sorunlarından bir tanesinin de nitelikli ara eleman ihtiyacı olduğu belirtilmektedir (Malkoçoğlu ve ark., 2015; Kalkınma Bakanlığı, 2015; TOBB, 2018). Mobilya sektöründeki çalışma oranlarının düşük olması dikkat çeken bir durum oluşturmaktadır.

Öğrenciler açısından bir işe yerleşmedeki en önemli faktörün tecrübe (\%47) olduğu, iş yerinde kendilerinde yetersiz/eksik gördükleri faktörlerin ise yabancı dil (\%38) ve tecrübe/deneyim (\%36) olduğu belirlenmiştir. Mobilya sektörü ülkemiz ekonomisine ve istihdamına katkı sağlayan ve her geçen gün değişen ve gelişen dinamik, en önemli üretim sektörlerdendir. İhracat odaklı bir sektördür ve bu nedenle yabancı dil sektörde önem arz etmektedir. Öğrencilerin kendilerinde yetersiz gördüğü bu durumun iş hayatına başlamadan önce okulda alacakları eğitimle geliştirilebileceği düşünülmektedir. Bu nedenle yabancı dil hazırlık sınıflarının bu öğrenciler için de uygulanması yabancı dillerinin gelişimine olumlu katkı sağlayabilir.

Literatürde üniversite sanayi işbirliğinin yeterli seviyede sağlanamamasının Meslek Yüksekokullarının önemli sorunlarından bir tanesi olduğundan söz edilmektedir (Göktürk, 2013; Alkan, 2014; Aydın ve ark., 2019). Bu çalışmada öğrencilerin okulda aldıkları uygulama-pratik ve alınan eğitimlerin yeterli olduğunu düşündükleri anlaşılmıştır. Meslek Yüksekokulları mesleğe yönelik eğitim veren kurumlardır. Dolayısıyla uygulama dersleri mesleki katkı sağlaması açısından çok önemlidir.

Okul-meslek ve üniversite-sanayi işbirliğine yönelik elde edilen bulgularda genel çerçevede katılma oranlarının katılmama oranlarından fazla olduğu görülmektedir. Mezunların üniversite sanayi işbirliği çerçevesinde aldıkları eğitimlerin, mesleki gelişimlerine olan katkısının çok önemli oranlarda olduğu ifade edilebilir. Aynı zamanda kendi sektörlerini tanıma, kavrama, kullanılan makine ve teçhizatlar ve işleyişi hakkında bilgi sahibi olma ve iletişim becerilerinin geliştirmesi açısından büyük fayda sağladığı görülmektedir. Bu bakımdan üniversite-sanayi işbirliği çerçevesinde gerçekleştirilen eğitimlerin öğrencilere mobilya sektöründe kullanılan yüksek maliyet gerektiren son teknolojik makine ve teçhizatın teknolojileri yerinde görme ve uygulama imkânını sağlaması, sektördeki gelişmeleri yakından görme fırsatı sunması, işleyişi kavrama ve yerinde öğrenme ile iş hayatlarına hazırlanmasına büyük katkı sağlamaktadır. Çetin ve ark., (2017) tarafından Biga Meslek Yüksekokulu Mobilya ve Dekorasyon Programında üniversite-sanayi işbirliği çerçevesinde gerçekleştirilen işbaş1 eğitim modeli uygulama örneği çalışmasında işyerindeki iş istasyonlarına göre her bir öğrencinin rotasyon kapsamında tüm birimlerde aktif biçimde yer aldığı, düzenli oryantasyon eğitimlerinin gerçekleştirildiği ve öğrencilerin sektördeki diğer firmaları ve gelişmeleri takip edebilmeleri açısından fuarlara katılımlarının sağlandığından söz etmektedir. Yanıtlardan üniversite-sanayi işbirliği çerçevesinde gerçekleştirilen uygulamalı eğitimin ve uygulanan bu modelin öğrenciler açısından önemli katkılarının olduğu sonucu ortaya çıkmış ve elde edilen sonuçların birbirini desteklediği anlaşılmıştır. Sonuç olarak hızla gelişen çağımızda bu gelişmelere uyum sağlanabilmesi için gerekli insan kaynağını yetiştiren üniversiteler ile yüksek alt yapı ve teknolojiye sahip olan bu kurumlarla iş birliğinin önemi ortaya çıkmıştır.

\section{Kaynaklar}

1. Adıgüzel, C. (2009). Meslek Yüksekokulu Öğrencilerinin İşyeri Eğitimi Öğrenme Ürünlerinin Değerlendirilmesi. Ondokuz Mayıs Üniversitesi, Eğitim Fakültesi Dergisi, 27 (1), 115-128. 
2. Akşit, A., Kalfa, V. R., ve Arpa, B. (2016). Bir İşveren-Öğrenci Buluşması Modeli- Meslek Yüksekokullarında İşbaşı Eğitimi Programında Öğrenci Algılarının Belirlenmesi: Honaz Meslek Yüksekokulu Örneği. Uluslararası Osmaneli Sosyal Bilimler Kongresi, 12-14 Ekim.2016, Bilecik Şeyh Edebali Üniversitesi, Osmaneli Meslek Yüksekokulu, Osmaneli/Bilecik.

3. Alkan, R. M., Suiçmez, M., Aydınkal, M., Şahin, M. (2014). Current Situation İn Vocational Schools: İssues And Some Suggested Solutions. Journal Of Higher Education And Science, 4(3), 133-140.

4. Arpat, B. (2018). Meslek Yüksekokullarında Uygulanan İşbaşı Eğitimlerinde Boylamsal Bir Değerlendirme Honaz Meslek Yüksekokulu Örneği. MANAS Sosyal Araştırmalar Dergisi,7(3), 345-359.

5. Aydın, M., Merdan, R., ve Akyürekli, Ö. (2019). Yükseköğretimde Mesleki Eğitimin Önemi ve Bir Alan Araştırmasi-Importance Of Vocational Education In Higher Education And A Field Study. Mehmet Akif Ersoy Üniversitesi, Sosyal Bilimler Enstitüsü Dergisi, 9(21), 191-202.

6. Ceylan, H., ve Erbir, A.M. (2015). Meslek Yüksekokullarında Kalite: Mevcut Durum, Sorunlar ve Çözüm Önerileri. Electronic Journal of Vocational Colleges, 5(1), 99-106.

7. Çetin, F., Aşkın A., ve Kaygın B. (2017). Üniversite Sanayi İşbirliği İş Başı Eğitim Modeli Uygulama Örneği. Bartın Orman Fakültesi Dergisi, 19(2), 153-159.

8. Dündar, B. ve Bıçakçı, C. (2017). Meslek Yüksekokulu Öğrencilerinin Dikey Geçiş Sınavına Bakışı: Osmaniye Meslek Yüksekokulu Örneği. 21.Yüzyllda Ĕgitim ve Toplum Eğitim Bilimleri ve Sosyal Araştırmalar Dergisi, 6(16), 237-250.

9. Faik, A. (2010). Sektör Odaklı Eğitim Anlayışıyla Akdeniz Üniversitesi Spor Yöneticiliği Bölümünde Okuyan ve Mezun Öğrencilerinin Bölüm Tercihi ve Aldıkları Eğitim İle İlgili Düşüncelerinin Değerlendirilmesi. Uluslararası İnsan Bilimleri Dergisi, 7(2), 696-716.

10. Göktürk, İ. E., Aktaş M. A., ve Göktürk, Ü. (2013). Sosyal Bilimler Meslek Yüksekokullarının Eğitim Sürecinde; Uygulama Açısından Karşılaşılan Sorunlar ve Çözüm Önerileri. Electronic Journal of Vocational Colleges, 3(4), 1-8.

11. İmamoğlu, S. Z. (2004). Üniversite-Sanayi İşbirliği, GYTE E-Bülten, Sayı: 3 http://www.gtu.edu.tr/ebulten/sayi3/skimam.htm, Erişim tarihi: 05.04.2020.

12. Kalkınma Bakanlığı (2014). Mesleki Eğitimin Yeniden Yapılandırılması Çalışma Grubu Raporu. Onuncu Kalkınma Planı 2014-2018, Kalkınma Bakanlığı Yayınları, Yayın No: KB: 2898 - ÖİK: 738, Ankara/ Türkiye.

13. Kalkınma Bakanlığı (2015). Mobilya Çalışma Grubu Raporu. Onuncu Kalkınma Planı 2014-2018, Kalkınma Bakanlığı Yayınları, Yayın No: KB: 2915- ÖİK: 751, Ankara/Türkiye.

14. Kaysi F., Aydemir, E., Yavuz, M. (2019) Meslek Yüksekokulu Öğrencilerinin Mezuniyet Sonrasına Yönelik Hedeflerinin İncelenmesi. V.Uluslararası TURKCESS Eğitim ve Sosyal Bilimler Kongresi, 27-29 Haziran 2019, Tam Metin Kitapçığ: 399-406.

15. Korkmaz, M., (2015). Türkiye'de Mesleki Eğitim, İZTO AR-GE Bülten Dergisi, Ocak-Şubat: 38-45.

16. Koşan, A. (2003). Eğitimde Okul-Endüstri İşbirliği. Atatürk Üniversitesi Sosyal Bilimler Enstitüsü Dergisi, 2(1-2), 107-130.

17. Küçükgöksel, N., ve Akpınar, T. (2016). İstihdam Odaklı Mesleki Eğitime Yönelik Sorunlar, Talep ve Beklentiler. Tekirdăg S.M.M.M Odası Sosyal Bilimler Dergisi, Sayı: 6, 1-18.

18. Malkoçoğlu, A., Ataseven, F., Yıldırım, İ., Yaylı, K. (2015). Türkiye Mobilya Endüstrisi Büyük Ölçekli İşletmelerinin Sorunları ve Çözüm Önerileri. Selçuk-Teknik Dergisi,14(2), 729-746.

19. Sarıbıyık, M. (2013). Meslek Yüksekokullarında Nitelikli İşgücü Yetiştirmek İçin $3+1$ Eğitim Modeli. Akademik Platform Mühendislik ve Fen Bilimleri Dergisi,1(1), 39-41.

20. Sevim, Ş., ve Karamete, F. (2003). Meslek Yüksekokullarında Üniversite-Sanayi İşbirliği, Yöresel Kalkınmaya Etkisi ve Yerel Bazda Uygulama Örneği. Dumlupınar Üniversitesi Sosyal Bilimler Dergisi, (8), $1-16$.

21. Sönmez, M. (2011). Mühendis ve Mühendis Yardımcılarının Yaşam Boyu Öğreniminde Meslek Yüksekokullarının Rolü. Ejovoc (Electronic Journal of Vocational Colleges), 1(1), 1-7.

22. Ulus, L., Tuncer, N., ve Sözen, Ş. (2015). Mesleki Eğitim, Gelişim ve Yeterlilik Açısından Meslek Yüksekokullarının Önemi. Uluslararası Türk Eğitim Bilimleri Dergisi, (5), 168-185.

23. URL-1, (2020). Mobilya ve Dekorasyon Programı Bulunan Üniversiteler. https://yokatlas.yok.gov.tr/onlisans-program.php?b=30038, Erişim tarihi: 17.04.2020.

24. URL-2, (2020) Mesleki ve Teknik Orta Öğretim kurumlarından Meslek Yüksekokulları İle Açık Öğretim Önlisans Programlarına Sınavsız Geçiş. https://www.osym.gov.tr/ Eklenti/841,2004kilavuzosssonpdf.pdf?0 Erișim tarihi: 17.04 .2020

25. TOBB (2018). Türkiye Mobilya Ürünleri Meclisi Sektör Raporu 2017. Türkiye Odalar ve Borsalar Birliği Yayınlarl, Yayın No: 2018/304, Ankara, Türkiye.

26. Tuncer, M., ve Tanaş, R., (2019). Mesleki Ĕgitim Sorunsalının Meslek Yüksekokulları Bağlamında Öğrenci Görüşlerine Göre Değerlendirilmesi. Electronic Journal Of Education Sciences, 8(15), 76-88. 
27. Yörük, S., Dikici, A., ve Uysal, A. (2002). Bilgi Toplumu ve Türkiye’de Mesleki Eğitim. Fırat Üniversitesi Sosyal Bilimler Dergisi, 12(2), 299-312.

28. Yıldırım, H., Sertel, E., ve Akyol, Ö. S. (2017). Meslek Yüksekokullarının Güncel Sorunlarına İlişkin Öğretim Elemanlarının Görüşleri. Mehmet Akif Ersoy Üniversitesi Sosyal Bilimler Enstitüsü Dergisi, (9)21, 287-300.

29. Yıldırgan, R. (2016). Turizm İşletmeleri Yöneticilerinin 3+1 Eğitim Modeli Kapsamındaki Uygulama Öğrencilerine Yönelik Düşüncelerinin Değerlendirilmesi: Sakarya Üniversitesi Örneği. Nişantaş1 Üniversitesi Sosyal Bilimler Dergisi, 4(1), 19-29. 